Situs Jurnal : $\underline{\text { http://ejournal.stiepancasetia.ac.id/index.php/jieb }}$

Jilid 6 Nomor 2 Juli 2020

Hal 155 - 163

\title{
PENERAPAN FUNGSI MANAJEMEN PADA KANTOR KELURAHAN RANTAU KIWA KECAMATAN TAPIN UTARA KABUPATEN TAPIN
}

\section{Hamdi *}

Abstrak : Tujuan penelitian ini adalah untuk mengetahui penerapan fungsi manajemen pada kantor kelurahan Rantau Kiwa Kecamatan Tapin Utara Kabupaten Tapin yang selama ini dan membahas bagaimana penerapan fungsi manajemen yang seharusnya. Jenis penelitian adalah deskriptif yang memberikan gambaran mengenai penerapan fungsi-fungsi manajemen pada Kelurahan Rantau Kiwa Kecamatan Tapin Utara Kabupaten Tapin. Hasil penelitian menunjukkan bahwa pelaksanaan pekerjaan yang dilakukan di kantor kelurahan Rantau Kiwa masih ada yang dilaksanakan tumpang tindih, banyak pelayanan yang diharapkan masyarakat dalam penyelesaiannya terlambat dan cenderung lama, karena masing-masing pegawai saling menunggu siapa yang menyelesaikan pekerjaan, belum adanya evaluasi sehingga tidak dapat diukur dengan jelas sejauh mana kinerja masing-masing dalam bekerja memberikan pelayanan kepada masyarakat.

\section{Pendahuluan}

Pegawai Negeri Sipil (PNS)
sebagai aparatur pemerintah
memegang posisi sentral dalam
pelaksanaan pembangunan nasional.
Meskipun teknologi dewasa ini telah
berkembang sangat besar sehingga
menggeser dan menggantikan sebagian
besar tugas-tugas manusia, namun
faktor manusia masih sangat
diperlukan. Betapapun canggihnya
teknologi tidak akan berarti apa-apa
tanpa dibarengi dengan kemampuan
manusia untuk mengelolanya.
Manajemen dan organisasi
merupakan dua hal yang tidak bisa
dipisahkan. Organisasi merupakan
kesatuan dari dua atau lebih orang atau
kelompok tertentu untuk mencapai
tujuan tertentu, sedangkan manajemen
merupakan seni dan ilmu dalam
mengelola suatu hal agar tujuan yang
diinginkan tercapai dengan efektif dan
efisien. Organisasi dalam hal ini adalah
sebagai objek yang dituju sedangkan

manajemen adalah sebagai alat yang dapat digunakan untuk mencapai tujuan organisasi.

Kantor Kelurahan Rantau Kiwa Kecamatan Tapin Utara Kabupaten Tapin merupakan instansi pemerintah di Kabupaten Tapin. Dalam aktifitasnya kantor Kelurahan Rantau Kiwa Kecamatan Tapin Utara Kabupaten Tapin merupakan sebagai institusi pelayanan masyarakat tentunya harus memiliki manajemen organasisi yang baik, sehingga pelayanan yang diberikan dapat memberikan kepuasan yang tinggi bagi masyarakat.

Pada realitanya, Kantor Kelurahan Rantau Kiwa Kecamatan Tapin Utara Kabupaten Tapin perlu peningkatan dalam hal pelayanan kepada masyarakat khususnya dalam hal manajemen organisasi, hal ini dapat dilihat dari penerapan fungsi manajemen. (Kayo, 2014:32) fungsi fungsi manajemen terdiri dari 
palanning, organizing, actuating, organizing (POAC) yang belum optimal seperti :

a. Fungsi perencanaan, seperti dalam hal pengambilan Keputusan oleh lurah yang belum sepenuhnya berasal dari bidang yang bersangkutan.

b. Fungsi pengorganisasian, seperti dalam hal pembagian sistem wewenang atau tugas yang masih belum baik (perangkapan tugas).

c. Fungsi penggerakan, seperti masih rendahnya semangat kerja dan rendahnya fungsi pengawasan lurah yang dilakukan.

d. Fungsi pengawasan belum optimal, seperti kedisiplinan pegawai rendah, yang seharusnya sudah berhadir pada jam 08.00 Wita, akan tetapi banyak pegawai yang hadir jam 10.00 Wita dan pulang lebih awal dari yang ditentukan, da nada pulu yang datang jam 8 untuk absen datang saja, setelah itu kembali untuk absen pulang saja

Akibat dari keadaan ini tentunya pelayanan yang diberikan kepada masyarakat Kelurahan Rantau Kiwa Kecamatan Tapin Utara Kabupaten Tapin belum optimal, banyak urusan masyarakat yang tidak dapat diselesaikan tepat waktu sesuai yang diharapkan.

Melihat beberapa permasalahan diatas, penulis tertarik untuk melakukan penelitian tentang Penerapan Fungsi Manajemen Pada Kantor Kelurahan Rantau Kiwa Kecamatan Tapin Utara Kabupaten Tapin.

Berdasarkan permasalahan yang telah diuraikan diatas, maka dirumuskan permasalahannya sebagai berikut:

a. Bagaimana penerapan fungsi manajemen pada Kantor Kelurahan
Rantau Kiwa Kecamatan Tapin Utara Kabupaten yang selama ini ?

b. Bagaimana penerapan fungsi manajemen pada Kantor Kelurahan Rantau Kiwa Kecamatan Tapin Utara Kabupaten yang seharusnya?

\section{Dasar Pemikiran Teoritis Dan} Pengembangan Hipotesis

\subsection{Pengertian Manajemen}

Manajemen sangat penting bagi setiap aktivitas individu atau kelompok dalam organisasi untuk mencapai tujuan yang diinginkan. Manajemen berorientasi pada proses (process oriented) yang berarti bahwa manajemen membutuhkan sumber daya manusia, pengetahuan, dan keterampilan agar aktivitas lebih efektif atau dapat menghasilkan tindakan dalam mencapai kesuksesan (Torang, 2015: 165). Proses tersebut terdiri dari kegiatan-kegiatan manajemen, yaitu perencanaan, pengorganisasian, penggerakan, dan pengawasan.

\subsection{Fungsi Manajemen}

Untuk mencapai tujuan, organisasi harus menjalankan fungsi-fungsi manajemen. Menurut George R. Terry fungsifungsi manajemen terdiri atas: perencanaan (Planning), pengorganisasian (Organizing), penggerakan (Actuating), pengawasan (Controling) (POAC) (Kayo, 2014: 32).

\section{a. Perencanaan (Planning)} \begin{tabular}{rr}
\multicolumn{2}{r}{ Perencanaan adalah } \\
kegiatan yang akan
\end{tabular} dilaksanakan. Perencanaan adalah pengambilan keputusan (Usman, 2015: 77). Perencanaan adalah proses dasar yang digunakan untuk memilih tujuan dan 
menentukan

cakupan

pencapaiannya.

Suatu

perencanaan adalah suatu

aktivitas integrative yang

berusaha memaksimumkan

efektivitas seluruhnya dari suatu organisasi sebagai suatu sistem, sesuai dengan tujuan yang ingin dicapai.

b. Pengorganisasian (Organizing)

adalah Pengorganisasian mendistribusikan pekerjaan dan tugas-tugas serta mengkoordinasikannya untuk mencapai tujuan organisasi. Manullang berpendapat bahwa pengorganisasian adalah pengelompokan aktivitas yang akan dilakukan atau pendistribusian tugas dan fungsi kepada setiap individu yang ada dalam organisasi (Torang, 2015: 170).

\section{c. Penggerakan (Actuating)}

Actuating (penggerakan) adalah seluruh proses pemberian motivasi kerja kepada para bawahan sedemikian rupa. Sehingga mereka mampu bekerja dengan ikhlas demi tercapainya tujuan organisasi dengan efisien dan ekonomis (Munir dan Wahyu Ilaihi, 2015: 159). Actuating merupakan fugsi manajemen secara langsung berusaha merealisasikan keinginankeinginan organisasi, sehingga dalam aktivitasnya senantiasa berhubungan dengan metode dan kebijaksanaan dalam mengatur dan mendorong orang agar bersedia melakukan tindakan yang diinginkan oleh organisasi tersebut (Amin, 2016: 233).

\section{d. Pengawasan (Controlling)}

\section{Controlling}

(Pengawasan) merupakan salah satu fungsi manajemen yang berupa mengadakan penilaian dan sekaligus bila perlu mengadakan koreksi sehingga apa yang sedang dilakukan bawahan dapat diarahkan ke jalan yang benar dengan maksud tercapai tujuan yang sudah digariskan semula. Dalam pelaksanaan kegiatan pengawasan, atasan mengadakan pemeriksaan, mencocokkan serta mengusahakan agar kegiatankegiatan yang dilaksanakan sesuai dengan rencana yang telah ditetapkan serta tujuan yang ingin dicapai (Manullang, 2016: 24).

Kerangka berpikir dalam penelitian ini dapat digambarkan sebagai berikut:

Kantor Kelurahan Rantau Kiwa Kecamatan Tapin Utara KabupatenTapin

Kendala Penerapan Fungsi Manajemen Selama Ini :

1. Fungsi perencanaan pengambilan keputusan yang dilakukan oleh pimpinan

2. Fungsi pengorganisasian dalam pembagian sistem wewenang yang baik, sehingga pekerjaan dapat selesai dengan baik

3. Fungsi penggerakan yang dilakukan oleh pimpinan yang mampu membangkitkan semangat kerja

4. Fungsi pengawasa terhada kedisiplinan pegawai dalam waktu kerja.

Penerapan Fungsi Manajemen ( POAC ):

1. Perencanaan (Planning),

2. Pengorganisasian (Organizing),

3. Penggerakan (Actuating),

4. Pengawasan (Controling) 
Fungsi Manajemen Yang baik Dan

Tujuan organisasi secara optimal dapat tercapai

Gambar 2.1 : Kerangka Berpikir

Sumber : Data Diolah

\section{Metode Penelitian}

\section{1 Jenis Penelitian}

Adapun jenis penelitian yang diusung dalam penelitian ini adalah jenis penelitian deskriptif. Penelitian deskriptif digunakan jika penulis ingin memberikan gambaran yang lebih lengkap mengenai penerapan fungsi-fungsi manajemen pada Kelurahan Rantau Kiwa Kecamatan Tapin Utara Kabupaten Tapin.

\subsection{Populasi dan Sampel}

\subsubsection{Populasi}

Populasi adalah wilayah generalisasi yang terdiri atas: obyek/subyek yang mempunyai kualitas dan karakteristik tertentu yang ditetapkan oleh peneliti untuk dipelajari dan kemudian ditarik kesimpulannya (Sugiyono, 2014:80). Populasi dalam penelitian ini yaitu pegawai Kelurahan Rantau Kiwa Kabupaten Tapin yaitu 13 orang pegawai di Kelurahan Rantau Kiwa

\subsubsection{Sampel}

Sampel adalah bagian dari jumlah dan karakteristik yang dimiliki oleh populasi tersebut

(Sugiyono, 2015:120). Penentuan jumlah sempel sangat tergantung dari karakteristik dan jumlah populasi. Apabila jumlah populasi dapat diketahui secara jelas jumlahnya, maka dapat digunakan beberapa rumus atau tabel. Pada penelitian ini berjmlah 3 (ltiga) orang yang terdiri sebagi berikut :

1. Lurah

2. Sekertaris Lurah

3. Staf 1 orang

\section{Analisis Hasil Penelitian dan Pembahasan}

4.1. Penerapan fungsi manajemen pada Kantor Kelurahan Rantau Kiwa Kecamatan Tapin Utara yang selama ini.

1. Bentuk

Pelaksanaan

Perencanaan Kantor

Kelurahan Rantau Kiwa

Kecamatan Tapin Utara

Berdasarkan hasil

wawancara dengan Lurah

Rantau Kiwa Kecamatan Tapin

Utara, perencanaan jangka panjang yang dilakukan pada kantor Kantor Kelurahan Rantau Kiwa Kecamatan Tapin Utara adalah dengan melakukan Penyusunan Rencana Jangka Panjang Dan Menengah (RPJMP) dimana hal ini harus tertuang didalam Renstra (Rencana Strategi) Kelurahan Rantau Kiwa yang berjangka dalam perencanaan untuk 5 tahun. Adapun bentuk renstra di Kantor Kantor Kelurahan Rantau Kiwa Kecamatan Tapin Utara selama adalah sebagai berikut :

1. Program pelayanan administrasi perkantoran

2. Program peningkatan sarana dan prasarana aparatur

3. Program peningkatan disiplin aparatur

4. Program peningkatan kapasitas sumber daya aparatur 
$\begin{array}{lr}\text { 5. Program peningkatan } \\ \text { pengembangan } & \text { sistem } \\ \text { pelaporan capaian } & \text { kinerja } \\ \text { dan keuangan. } & \\ \text { Perencanaan } & \text { juga }\end{array}$ dilakukan hanya oleh Lurah KRantau Kiwa Kecamatan Tapin Utara, yaitu lurah, dengan melakukan perencanaan jangka pendek. Hasil wawancara penulis adalah bahwa perencanaan ini dilakukan oleh pimpinan dalam bentuk pelaksanaan kegiatankegiatan kecamatan baik yang bersifat rutin saja, maupun yang sifatnya insidentil.

Perencanaan

juga

dilakukan untuk melaksanakan kegiatan-kegiatan rutin tahunan maupun insidentil perintah dari kepala daerah, yang dikatakan sebagai perencanaan jangka pendek untuk menyelesaikan pekerjaan operasional dadakan.

2. Bentuk

Pelaksanaan

Pengorganisasian Kantor Kelurahan Rantau Kiwa Kecamatan Tapin Utara

Berdasarkan hasil
wawancara dengan Lurah
Rantau Kiwa Kecamatan Tapin
Utara dapat dijelaskan bahwa
proses pengorganisasian tim
kerja untuk pencapaian target
jangka panjang disusun sesuai
peraturan perundang-undangan
tentang Organisasi Kecamatan
dan Kelurahan Kabupaten
Tapin, agar pelaksanaan tugas
di Kecamatan dan Kelurahan
Kabupaten Tapin lebih berdaya
guna dan berhasil guna.
Pengorganisasian tim kerja
jangka pendek ini meliputi
pengorgaisasian tim kerja
dalam menyelesaikan pekerjaan
kantor baik kegiatan rutin

tahunan seperti penyelenggaran upacara, MTQ dan lain-lain.

3. Bentuk

Pelaksanaan

Penggerakan Kantor

Kelurahan Rantau Kiwa Kecamatan Tapin Utara

Fungsi penggerakan dalam manajemen adalah relaisasi dari seluruh perencanaan dan penggorganisasian, apakah dapat diwujudkan atau tidak dalam tindakan nyata. Wujud nyata dalam melaksanakan seluruh pekerjaan kantor baik dalam mewujudkan pekerjaan yang telah ditetapkan untuk keberhasilan jangka panjang maupun jangka pendek, pada kantor Kantor Kelurahan Rantau Kiwa Kecamatan Tapin Utara berdasarkan hasil wawancara dengan pimpinan kantor dijelaskan bahwa dilakukan dengan memberikan program motivasi dan pemberian bonus-bonus tertentu. Agar dalam melaksanakan tugas pekerjaan yang telah ditetapkan dapat terlaksana dengan baik, pimpinan kantor memberikan program motivasi dan pengarahan kerja. Wujud nyata dari program ini dilakukan setiap pagi sebelum aktivitas kerja dilakukan dengan nama program apel pagi. Apel pagi merupakan wujud dari pemotivasian para pegawai kantor dalam bekerja, dalam apel pagi pimpinan akan memberikan support, semangat dan arahan kerja, juga berkaitan dengan pemberian informasiinformasi terbaru dari pemerintah daerah.

Program kedua yang dilakukan dalam memberikan motivasi agar pelaksanaan 
berjalan sesuai dengan yang diharapkan juga dilakukan dengan memberikan motivasi kepada pegawai dengan pengusulan kenaikan pangkat serta promosi jabatan, hal ini tentu akan membawa dampak positif kepada pegawai dalam penyelesaian dan pelayanan kepada masyarakat.

\section{Bentuk}

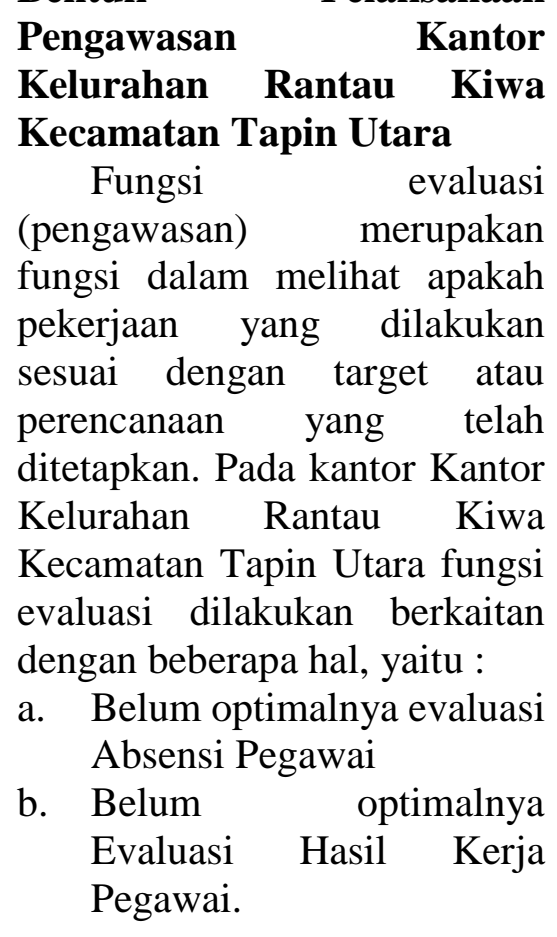

\subsection{Penerapan Fungsi Manajemen} Pada Kantor Kelurahan Rantau Kiwa Kecamatan Tapin Utara $\begin{array}{lll}\text { Kabupaten } & \text { Tapin Yang } \\ \text { Seharusnya } & \end{array}$

\section{Bentuk Pelaksanaan Peren- canaan ( Planning )}

Perencanaan adalah suatu proses dasar yang digunakan untuk memilih tujuan dan menentukan cakupan pencapaiannya yang berusaha memaksimumkan efektivitas seluruhnya dari suatu organisasi sebagai suatu sistem, sesuai dengan tujuan yang ingin dicapai, perencanaan yang seharusnya dilakukan pada kantor Kelurahan Rantau Kiwa Kecamatan Tapin Utara adalah yaitu :

1. Perencanaan yang dilakukan oleh Lurah bersama-sama dengan kepala bagian dan seksi yang ada.

2. Perencanaan yang sudah disusun selanjutnya dapat dikomunikasikan kepada seluruh pegawai yang ada di Kantor Kelurahan Rantau Kiwa Kecamatan Tapin Utara, sehingga semua pegawai mengerti dan memahami apa tujuan dan target yang ingin diacapai untuk masa depan.

3. Menerima masukan dan saran dari semua pegawai yang ada tentang perencanaan yang telah disusun, sehingga menjadi sebuah keputusan bersama.

2. Bentuk Pelaksanaan Pengorganisasian (Organiziing)

Pengorganisasian

merupakan aktifitas dalam melakukan penyusunan tim kerja untuk menyelesaikan pekerjaan yang tetapkan untuk mencapai target organisasi yang efektif dan efisien, bentuk Pelaksanaan Pengorganisasian (Organiziing) yang seharusnya pada kantor Kelurahan Rantau Kiwa Kecamatan Tapin Utara dengan cara yaitu :

1. Sesuai dengan perencanaan yang dilakukan meliputi perencanaan jangka panjang dan jangka pendek, maka untuk mengorganisasikan kegiatan kantor dalam mencapai target jangka 
panjang dan jangka pendek juga dilakukan penyusunan tim kerja dalam bentuk jangka panjang dan jangka pendek.

2. Pengorganisasian kerja di Kantor Kelurahan Rantau Kiwa Kecamatan Tapin Utara sebaiknya dilakukan dengan menjelaskan lebih rinci tentang deskripsi pekerjaan setiap pegawai dalam bagian dan seksinya masing-masing, serta sebaiknya pegawai ditempatkan pada level kompetensi yang sesuai dengan yang dimilikinya seperti bagian keuangan yang mengerti tentang ilmu akuntansi ataupun bagian pemerintahan yang mengerti tentang ilmu pemerintahan (dari Institut Pemerintahan Dalam Negeri).

\section{Bentuk Pelaksanaan Pengge-} rakan ( Actuating )

Untuk dapat mewujudkan pekerjaan yang telah ditetapkan untuk keberhasilan jangka panjang maupun jangka pendek, maka bentuk pelaksanaan penggerakan yang seharusnya di Kantor Kelurahan Rantau Kiwa Kecamatan Tapin Utara yaitu :

1. Dengan mengkombinasikan berbagai metode motivasi, sehingga menghilangkan

kebosanan dengan sistem ceramah setiap rapat koordinasi setiap minggu pada hari senin.

2. Penggerakan terhadap metode motivasi tersebut dapat melalui pengarahan dan bimbingan yang dilaksanakan secara kontinyu, Lurah Rantau Kiwa Kecamatan Tapin Utara pada semua personil dan pegawai di lingkungan Kelurahan Rantau Kiwa dan pada pegawai struktural di dalam organisasi kerjanya.

\section{Bentuk Pelaksanaan Penga- wasan (Controling )}

Pengawasan merupakan salah satu fungsi manajemen yang berupa :

1. Mengadakan penilaian terhadap pekerjaan staf atau pegawai secara berkala.

2. Mengadakan koreksi sehingga apa yang sedang dilakukan bawahan dapat diarahkan ke jalan yang benar dengan maksud tercapai tujuan yang sudah digariskan semula. Dalam pelaksanaan kegiatan pengawasan, atasan ( lurah ) seharusnya mengadakan pemeriksaan, mencocokkan serta mengusahakan agar kegiatan-kegiatan yang dilaksanakan sesuai dengan rencana yang telah ditetapkan serta tujuan yang ingin dicapai. Fungsi evaluasi di Kantor Kelurahan Rantau Kiwa Kecamatan Tapin Utara hendaknya harus sangat diperhatikan dengan baik. Menetapkan indikator ukuran standar pencapaian kinerja baik organisasi maupun pegawai terhadap pelayanan masyarakat (seperti Standar Pelayanan 
Publik sesuai Permenpan No. 16 Tahun 2014), sehingga dapat terukur dengan jelas.

\section{Kesimpulan}

Penerapan fungsi manajemen pada Kantor Kelurahan Rantau Kiwa Kecamatan Tapin Utara selama ini yaitu :

1. Fungsi perencanaan jangka panjang Rencana Strategis (renstra) Kantor Kelurahan Rantau Kiwa Kecamatan Tapin Utara tersebut banyak pegawai menyatakan tidak pernah tahu dengan adanya renstra tersebut.

2. Fungsi pengorganisasian tidak dijelaskan dalam bentuk job deskripsi dan job spesifikasi yang menjadikan pelaksanaan pekerjaan yang tumpang tindih, banyak pelayanan yang diharapkan masyarakat selesai terlambat dan cenderung lama, karena masingmasing pegawai saling tunggumenunggu siapa yang menyelesaikan pekerjaan.

3. Fungsi penggerakan dalam memberikan arahan apel pagi cenderung menjadi terasa menggurui dan sifatnya telah membosankan karena banyak hal itu-itu saja yang disampaikan.

4. Fungsi pengawasan sangat minim sekali dilakukan oleh pimpinan maupun kepala bagian dan seksi masing-masing, hal inilah menyebabkan kurang baiknya kinerja pegawai karena pekerjaan mereka tidak ada evaluasi yang terstandar sehingga tidak dapat diukur dengan jelas sejauhmana kinerja mereka masing-masing dalam bekerja memberikan pelayanan kepada masyarakat.

Penerapan fungsi manajemen pada kantor Kelurahan Rantau Kiwa Kecamatan Tapin Utara yang seharusnya adalah :
1. Fungsi Perencanaan yang dilakukan Lurah yaitu dengan kepala bagian dan seksi, mesti dikomunikasikan kepada seluruh pegawai, sehingga semua pegawai mengerti dan memahami apa tujuan dan target yang ingin diacapai untuk masa depan.

2. Fungsi pemotivasian pegawai sebaiknya dilakukan dengan mengkombinasikan berbagai metode motivasi, sehingga menghilangkan kebosanan dengan sistem ceramah setiap apel pagi.

3. Fungsi pengorganisasian kerja sebaiknya dilakukan dengan menjelaskan lebih rinci tentang deskripsi pekerjaan setiap pegawai dalam bagian dan seksinya masing-masing, serta sebaiknya pegawai ditempatkan pada level kompetensi yang sesuai dengan yang dimilikinya.

4. Fungsi evaluasi hendaknya dapat memperhatikan dengan baik dan sebaiknya dengan cara menetapkan indikator ukuran standar pencapaian kinerja baik organisasi maupun pegawai, sehingga dapat terukur dengan jelas.

\section{DAFTAR PUSTAKA}

Diah Kumalasari, 2015, Penerapan Efisiensi dan Efektivitas Melalui Fungsi-Fungsi Manajemen Pada Kecamatan Gubukrubuh Gunung Kidul,

http://e.journal.skripsi_manajemen. blogspot.com (13/10/2017)

Fatimah, 2016, Penerapan Fungsi Manajemen Pada Kecamatan Karang Intan Kabupaten Banjar, Skripsi, STIE Pancasetia, Banjarmasin 
Handoko, Hani T, 2015, Manajemen Personalia dan Sumber Daya Manusia. Yogyakarta : BPFE

Handoko, Hani T, 2015, Manajemen Personalia dan Sumber Daya Manusia. Cetakan Kelima. Yogyakarta : BPFE

Hasibuan, Malayu S.P. 2016. Manajemen : Dasar, Pengertian, dan Masalah. Edisi Revisi. Jakarta : Bumi Aksara.

Jufrizal, 2016, Penerapan Fungsi-Fungsi Manajemen Pada Kantor Camat Kepenuhan Kabupaten Rokan Hulu Provinsi Riau, http://e.journal.skripsi_manajemen. blogspot.com (13/10/2017)

Kayo, Ridwan, 2015. Manajemen. Jakarta : PT. Bumi Rajagrafindo Persada.

Moleong, 2015, Teknik Analisis Data Dalam Subuah Penelitian, PT. Bumi Rajagrafindo Persada Jakarta
Robbins Stephen. 2015. Organizational Behaviour. Alih bahasa Benyamin Molan. PT. Index, Kelompok Gramedia. Jakarta.

Sekaran, Umar, 2015, Metodelogi Penelitian, Salemba Empat, Jakarta

Siswanto, Sastrohadiwiryo. 2016. Manajemen Modern, Konsep dan Aplikasi. Bandung Sinar Baru.

Torang, 2015. Sistem Perencanaan dan Pengendalian Manajemen, Penerbit Salemba Empat, Jakarta.

Usman, Sinaung, 2016, Fungsi Manajemen dalam Prakteknya, Rineka Cipta, Jakarta

Wijayanti, 2016. Manajemen. Mitra Cendikia, Yogyakarta. 